\title{
Critical health-disease transition in the family: Nursing intervention in the lived experience
}

\author{
Transição saúde-doença crítica na família: Intervenção de enfermagem na experiência vivida
}

Transición entre salud y enfermedad crítica en la familia: Intervención de enfermería en la experiencia vivida

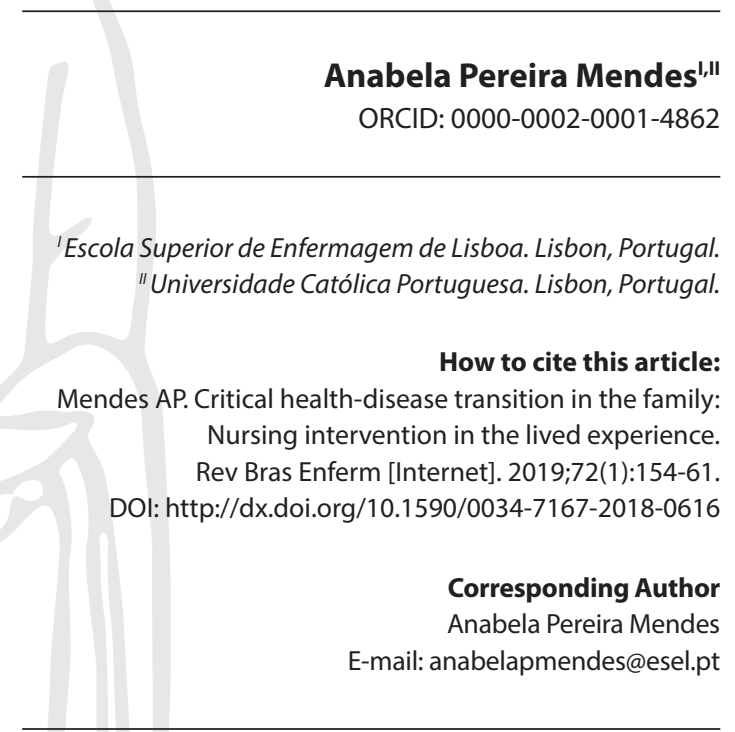

Submission: $08-20-2018$

Approval: 08-26-2018

\section{ABSTRACT}

Objective: To analyse the strategies found by families to deal with the situation of critical illness, in their lived experience in a family and in an inpatient context. Method: This research fits into a qualitative paradigm and a phenomenological approach, according to Van-Manen. Participants were referred to a "snowball" effect method and the data was collected through interviews with open-ended questions. Results: From the collected data three essential themes emerged revealing the strategies: Being aware; Building dialogue; Ensuring comfort. Final considerations: In the therapeutic intervention nurses verify that families facing a critical-illness interact between themselves and with the ICU team. Families interacting with nurses can find cognitive and emotional support allowing them to be aware of the situation and to speak about it in order to strengthen and to comfort themselves.

Descriptors: Family; Critical Illness; Intensive Care; Nursing Care; Comfort.

\section{RESUMO}

Objetivo: Analisar as estratégias encontradas pelas famílias para lidar com a situação de doença crítica, em sua experiência vivida dentro do contexto familiar e de internação hospitalar. Método: Trata-se de uma pesquisa qualitativa com abordagem fenomenológica, de acordo com os preceitos de Van-Manen. Os participantes foram encaminhados para um método que exerce um efeito "bola de neve". Os dados foram coletados por meio de entrevistas com perguntas abertas. Resultados: A partir dos dados coletados, emergiram três temas essenciais: Estando consciente; Construção do diálogo; Garantindo conforto. Considerações finais: Na intervenção terapêutica, os enfermeiros verificam que as famílias que enfrentam uma doença em estado terminal interagem entre si e com a equipe da UTI. As famílias que interagem com os enfermeiros podem encontrar apoio cognitivo e emocional, permitindo-lhes ter consciência da situação e falar sobre, a fim de se sentirem fortalecidos e confortados.

Descritores: Família; Estado Terminal; Tratamento Intensivo; Cuidados de Enfermagem; Conforto.

\section{RESUMEN}

Objetivo: Analizar las estrategias encontradas por las familias para lidiar con la situación de enfermedad crítica, en su experiencia vivida dentro del contexto familiar y de internación hospitalaria. Método: Se trata de una investigación cualitativa con enfoque fenomenológico, de acuerdo con los preceptos de Van-Manen. Los participantes fueron encaminados a un método que ejerce un efecto "bola de nieve". Los datos fueron recolectados por medio de entrevistas con preguntas abiertas. Resultados: A partir de los datos recolectados, surgieron tres temas esenciales: Estando consciente; Construcción del diálogo; Garantía de confort. Consideraciones finales: En la intervención terapéutica, los enfermeros comprueban que las familias que enfrentan una enfermedad crítica interactúan entre sí y con el equipo de la UTI. Las familias que interactúan con los enfermeros pueden encontrar apoyo cognitivo y emocional, permitiéndoles tener conciencia de la situación y hablar sobre, a fin de sentirse fortalecidos y confortados.

Descriptores: Familia; Estado Crítico; Tratamiento Intensivo; Cuidados de Enfermería; Confort. 


\section{INTRODUCTION}

Critical illness reveals an enormous fragility since it brings to family an intrepid experience of physical and emotional suffering. From the point of view of Meleis and collaborators ${ }^{(1)}$ vulnerability experiences are a result or arising from transitions that he calls "situational", "development", "health-disease" or "organizational". Regarding the health-disease transition the way each family member, related to the sick person, reacts to the event is distinctive and it can be seen in their daily lives.

In an understanding register of the impact facing critical illness, it is important to analyse the family concept in order to understand why it is disturbing the vulnerability of one of its members. To Sampaios' and collaborators perspective ${ }^{(2)}$, the term "family" reveals that the elements are emotionally connected. So we must work with different presentations of families to understand deeply their essence and the impact of situations. So we have the traditional nuclear family (parents and children), the extended family (extended family with several generations) and significant elements (friends, teachers, neighbours, etc.), as well as with the community around it, as the family is in a continuous relationship with the environment ${ }^{(2)}$. We noticed that family in his daily life incorporates knowledge and experience coming from external influences, and self-organisational capacity, coherence, consistency and balance coming from internal forces ${ }^{(3)}$.

Family gets identity and is built up with their co-existence in happiness and suffering, in discovering perspectives and strategies and sharing feelings and knowledge ${ }^{(4)}$. For Souza and collaborator $^{(5)}$ the bond between family members can be very significant, assuming they are the extension of each other. They share interests, beliefs and values, influence each other with emotional intensity, and encounter reciprocal expectations ${ }^{(5)}$. This way of coexisting strengthens each individual person and the whole. According to Relvas ${ }^{(3)}$, each family has its own dynamism and organization, which gives it individuality and autonomy. Considering this willingness to act with a view to understand the world they share, and how to react, in particular, to a critical disease situation of one of its members, the intention was to reveal the family lived experience and the way they become aware of the situation, build up a dialogue among themselves and support each other facing the inpatient unit adversity and the exterior.

\section{The health-disease transition in the family: Problems and intervention strategies}

According to Chick and Meleis's view ${ }^{(6)}$, the Transition refers to a period or a lived experience between two stable moments involving the person's life process moments of continuity and discontinuity. There is a before and after, which led them to intervene. Meleis ${ }^{(1)}$ points out that there is "from this" and "in this" experience a reformulated and fluid identity, as a result of the communion between the existing identity and the present conception. It identifies a person over the process and which outcomes from it. Meleis and collaborators $^{(7)}$ refer that Transition, as complex person-environment interaction, reveals the process' process and outcomes. Transition is the process and the result of it. The critical illness process indicates that in its essence the situation refers to the intensity of the facts.
Diagnosis, the definition of the prognosis and the therapeutic process were moments of great fragility.

Family members seek determinedly to understand the facts interacting with each other and with people from inpatient context who bear the main responsibility of taking care. This way the lived experience allows them to have a close contact with their suffering and vulnerability and of those with whom they interact with. In its continuous health-disease exercise experience of one of its members, family lives in a transition situation that reveals, increasingly, what illness means and which implications will follow. In human interactions process, King $^{(8)}$ states that persons in the living process of interaction react to people, events, and things, according to their values, perceptions, expectations, and needs.

From this statement we understand that intervening in the family at this stage of its life involves a detailed understanding of its constitution, its dynamics and its perspective.

According to Fernandes and collaborators ${ }^{(9)}$, nurses therapeutic interventions with families must be focused and will depend on their own concept of family. Working in so many places, with families living different process of transition, nurses should have the expertise and skills needed to evaluate and intervene in the family ${ }^{(9)}$. It is noted that an intervention in conformity with technical and relational competence enables the understanding of the family situation, and the necessary comfort ${ }^{(10)}$.

\section{OBJECTIVE}

This study aims to analyse the strategies found by families to deal with the situation, in their lived experience in a family context and in the inpatient context.

\section{METHOD}

\section{Ethical aspects}

After being duly informed about the study and about what will be asked him as a participant, a voluntary acceptance to participate in the study was obtained in a separate document, known as Informed Consent Term. This document assumes that adequate information has been shared on research, ensuring that the participant has the ability to understand it, to deliberate and to freely decide whether he wants or not to participate in the research ${ }^{(11)}$.

In order to assure confidentiality and anonymity, only the investigator knew the origin of the detailed narrative descriptions. Thus the data source has always been presented in a coded form [Family Member + interview number - example: FM2].

In the ethical evaluation of the investigation procedures, the study was reviewed by Portuguese Catholic University that ensured that ethical principles related to the research were fulfilled.

\section{Theoretical and methodological frameworks}

In the phenomenological approach it was verified that Van Manen ${ }^{(12)}$ would be a safe and reliable source from the existing theoretical frameworks. His written record leads the investigator through the research, allowing him to know accurately the participants lived experience. Van Manen makes them intentionally visit 
their past, every moment in life, each interaction and the meaning and essence of the same ${ }^{(4)}$. To Van Manen ${ }^{(12)}$, when we think in lived experience we must imagine a past period-of-time, there is always a temporal structure. In this perspective, it should never be seen as an immediate sign, but only as a reflection of a presence in the past. Regarding Davidsen ${ }^{(13)}$ and Giorgi \& Sousa's ${ }^{(14)}$ interpretation, the phenomenology proposes or impels reflection. It shows how situations are passed through the person and the person through them, in their individuality and intimacy ${ }^{(4)}$. Benner, Kyriakidis \& Stannard ${ }^{(15)}$, in their clinical nursing monitoring path, emphasize that understanding the essence and the experience meaning is decisive for critical care of nursing practice. It is verified that this methodological option makes sense in a nursing study, since the qualitative phenomenological objectives research is to deal with experiences and meanings $s^{(13)}$.

To Van Manen ${ }^{(12)}$, the hermeneutical significance of lived experiences come from as soon as we gather them (reflexively), when we attribute them a memory, The main goal is to reach the meaning of experiences lived by the subjects and to give them voice, both oral and written ${ }^{(14)}$. Phenomenology proposes a presence, an accurate description of the phenomena, being faithful, looking at things as they are, as they happen, thus revealing their essence, and who implies coexistence and participation ${ }^{(16)}$.

Van Manen ${ }^{(12)}$ leaves a work matrix with clear steps considering the activities of phenomenological research, based on a relationship of proximity among them. Each step has been respected throughout the investigative process: Back to a phenomenon that matters; to investigate the experience as it is lived and not as it is conceptualized; Reflecting on the essential themes that characterize the phenomenon; Describing the phenomenon through the art of writing and rewriting; Keeping a consistent pedagogical relationship with the phenomenon; Taking stock of the research context, considering the whole and the parts ${ }^{(12)}$.

\section{Type of study}

The study intended to talk with family members and from their narrative, to learn about their lived experience facing the critical health disease transition in family. This concern refers to a qualitative work nature and to a phenomenological approach. For Van Manen ${ }^{(12)}$ the lived experience is the departure and arrival point for the phenomenological investigation. The experiences and meaning structures (themes), as lived experiences, can be described and interpreted, constitute the immense complexity of the living world ${ }^{(12)}$. For David$\operatorname{sen}^{(13)}$ language is determinant to the rich description of experience aspects, is the main instrument in the phenomenological methods.

The lived experience can be seen in narrated words during the interview moments ${ }^{(4)}$. Van Manen ${ }^{(12)}$ maintains that the phenomenology purpose is to transform lived experience into a textual expression, that is at the same time reflexive, a relief and an appropriation.

\section{Methodological procedures}

Considering the above and the lived experience we intend to know how the family builds awareness of facts and the dialogue between people involved. Three research questions were defined in the methodological design:

- How is the family aware of its family member's critical illness situation?

- How does family build dialogue between the different members of the family and the care team in the inpatient context?

- How do you ensure family comfort on a daily basis?

Considering that the concept of family can take many forms depending on both individual and family history, biological, legal and/or religious status among other aspects ${ }^{(17)}$, members of the family were considered as participants in this study ${ }^{(18)}$ with a meaning in the life of the person with critical illness who was hospitalized in the ICU.

These participants were intentionally selected, considering the purpose of the research, the relevance of the cases, the possibility of richness in detail and the incursion into the situation and its adequacy ${ }^{(19)}$.

Inclusion criteria were considered for the participants: Understanding and speaking Portuguese, English or Spanish; Being over 18 years old; Having visited the person at the hospital at least once; Feeling physical and psychological comfortable to talk about the phenomenon under study.

Exclusion criteria were considered for the participants: Family member under the age of 18; Family member with physical or psychological instability, observed or referred, to talk about the phenomenon under study.

\section{Data source}

There were 18 individual interviews to adult family members of an adult person who was admitted to an ICU. The average duration of interviews was 60 minutes. Participants were between 23 and 58 years old; there were 13 women and 5 men.

\section{Collection and organization of data}

The interview as a method of data collection presents different structures. Van Manen ${ }^{(12)}$ proposes an interview with open-ended questions in order to access the experience. For this author, in a hermeneutical ("interpretative") phenomenological approach, the interview with open-ended questions allows exploring the experiential narrative and provides the conversation about the meaning of his experience ${ }^{(12)}$. It allows a broad moment of the lived narration and, inherently, the verbal and non-verbal expression of its meaning and its vulnerability.

Starting from the first interview, the following emerged by reference of this participant in a "Snowball" method ${ }^{(20)}$. The interview took place in an organized way and for that to happen the availability and interest of the person was previously considered. Time and place for the interview was further managed by the participant and the researcher availability.

The recording of the interviews was requested and the verbatim transcription was performed. 


\section{Data analysis}

In order to support the organization, coding and analysis of data, knowing its extension, the use of Nvivo ${ }^{\circ}$ was fundamental. It is possible to generate themes and create models or illustrations to better display the findings. This support allows the validation of the coding and reveals how rigorous and systematic the process was.

The methods and data analysis techniques were suitable for the study. In this sense, Van Manen's ${ }^{(12)}$ framework has been followed by data coding, with approaches or appropriate approximations to the text or narratives produced, namely the holistic or sententious approach, the selective or highlighted approach or the detailed approach or line-by-line. This part of coding process involved systematic presentation of preliminary outcomes in groups of researches. This strategy is fantastic to new researchers because senior researchers produced important feedbacks.

From the perspective of Cohen, Kahn \& Steeves ${ }^{(21)}$, data analysis begins with data collection. It would be interactively interesting listening and reflecting on the essential themes, which characterize the phenomenon and gradually describe the phenomenon through the art of writing and rewriting ${ }^{(12)}$. It was noted that data approximation is essential when we want to know the lived experience of the people who become or reveal themselves as nursing clients.

The phenomenological approach focuses on the lived experience interpretation, referring to Cohen, Kahn \& Steeves ${ }^{(21)}$ that the knowledge gathered is essential for nursing care and as such is a subject for a nurse research. In their perspective, the care of nurse intervention must be in the meaning of patients lived experiences, because it allows them to know their needs and respond accordingly ${ }^{(21)}$ (Figure1).

\section{RESULTS}

In a very significant sum of data due to the narratives size, we were looking for the investigator focus in detailed answers to the research questions. In this respect, data analysis aimed to identify and list the issues that unravel the phenomenon under study.

From the analysis and interpretation held, family members lived the experience of health-disease transition with great intensity. They reveal that the sense of anguish is always present in their daily lives conditioning it.

The person with whom they most interact is the nurse asking questions to understand what is going on and to build awareness of the facts. Progressively, they learn how to build dialogue and to how to be in order to find their own comfort.

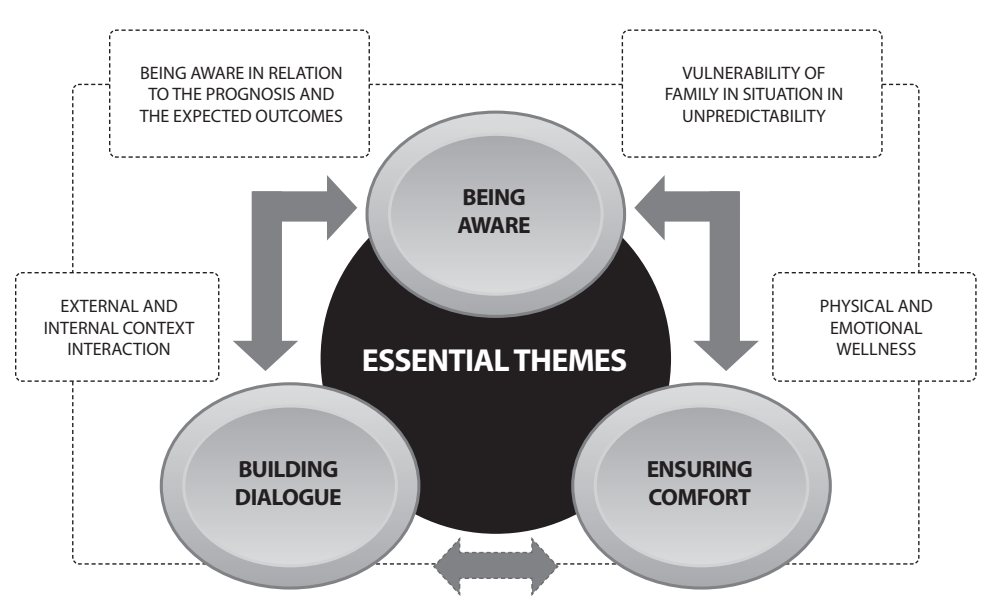

Figure 2 - The three essential themes: Family strategies in the health-disease transition

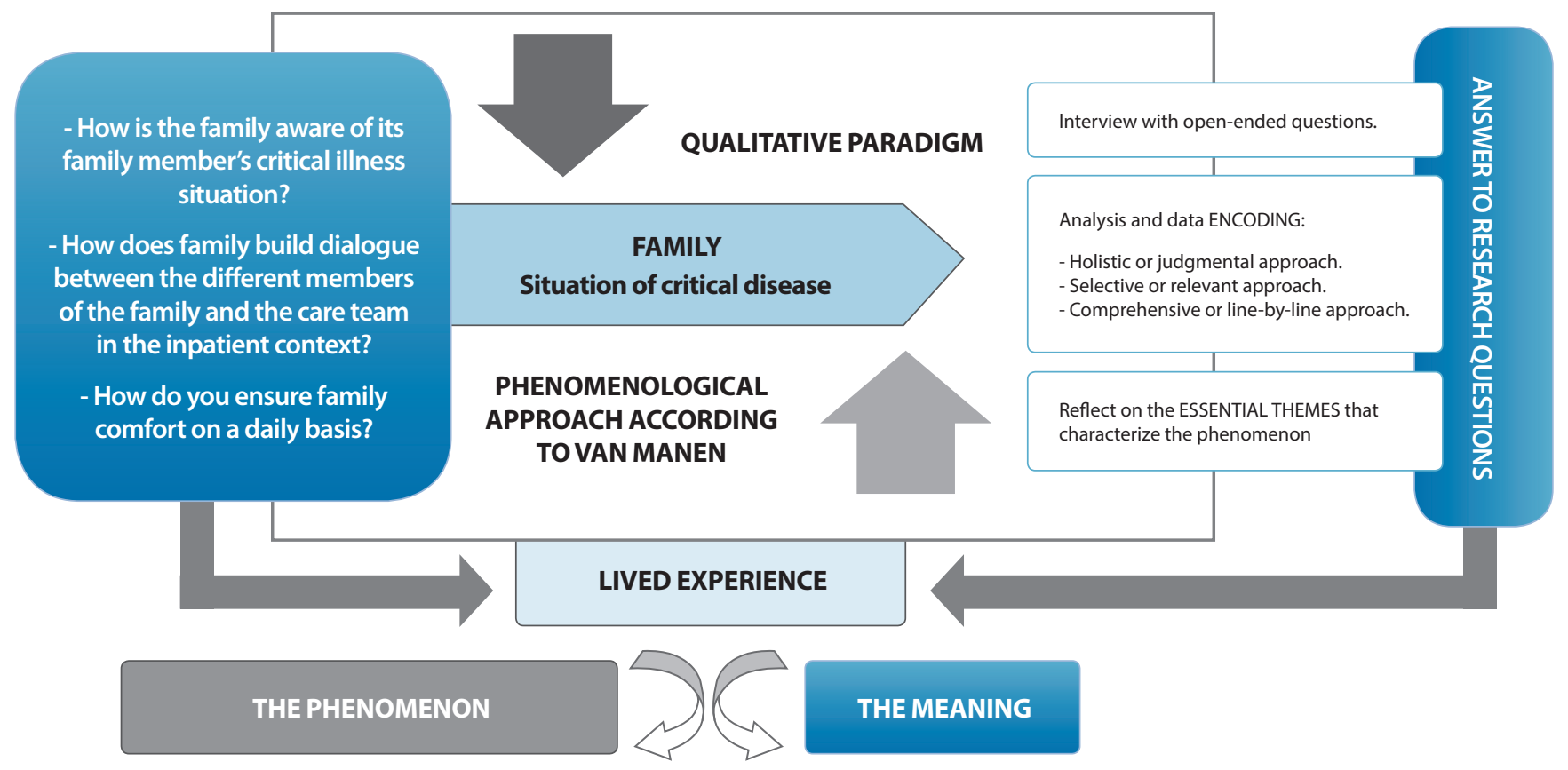

Figure 1 - Methodological Design - The phenomenon under study and the research questions 
In a critical illness situation, the experience turned out to be a huge weakness for people covered by the environment and proximity. They desire to feel embraced by the care team, particularly nurses, and to be identified as making part of the sick person's life considering their emotional fragility. In this area, three essential themes have been identified which reveals family strategies: Being aware; Building dialogue; Ensuring comfort (Figure 2).

\section{DISCUSSION}

The three essential themes arisen allow us to understand what meant for the family to take ownership of the situation and, by the awareness of the facts, in order to define strategies. The incessant search for knowledge and understanding is reflected in their daily life experiences.

They consider that when the strategies found are well founded they feel more comfortable and closer. It is intended to work now with each one of the key issues, revealing in the participants narrative "what they say" in a phenomenological approach, which structures the study.

\section{Being aware}

Due to its dimensions to know and understand the whole situation, the participant had to do an iterative way of details appropriation. Knowledge comforted them by alleviating the anguish experienced. McKiernan and collaborator ${ }^{(19)}$ realized that despite facing something so embarrassing, the family established in a regular basis a direct connection between being informed and knowing how to deal with the situation. They recognize that having knowledge and being aware of the prognosis and the expected outcomes has significantly helped to situate themselves in everyday life and to build trust.

The nurse support was essential to become aware and emerged as reference to be considered ${ }^{(22)}$. In the interaction achieved, the established communication and the acquired data proved to facilitate conditions to the transition experienced. Hinkle \& Fitzpatrick ${ }^{(23)}$ stated that this situation reveals to be a crisis time for family in their daily lives.

There is a process of learning [...] we learn, yes, we are forced to learn [...]. (FM9)

[...] at least family needs to get an appointment to receive information about what happened, because family needs to know if there is some progress or not, and which is the status [...] family always has many questions [...] because we do not know how things work [...]. (FM12)

[...] there was always a lot of attention [...] there was always a very sincere conversation, very open [...] they invited me to come in and they explained what was happening [...]. (MF10)

[...] to look for what the disease is and what it may come from, but then we want to know more [...] we are human and we thirst to always seek more and more [...]. (FM4)

We, only after things came to us, we start to research more and try to know more, and that's what we did on the Internet. (FM7)
According to Meleis and collaborators ${ }^{(1)}$, some of the process indicators that allow us to understand how the person lived the transition process are: The support found, the interaction performed, the way in which it was situated in the experience daily life, the trust built and the coping strategies used. It's appropriation path has phases and reveals a construction process and a deconstruction of the realized knowledge. Proença and collaborators $^{(24)}$ find that experiencing a relative hospitalisation in an ICU is intense and requires the family members' ability to understand their own feelings, to adapt to circumstances, and to develop strategies for sorting problem out. It is fundamental for the family to be understood and to have answers to their doubts, recognizing that their experience makes life insecure. Nurses can make the experience become easier due to the possibility of follow-up, clarification and explanation, in an attempt to become aware ${ }^{(25)}$.

\section{Building dialogue}

The family's intention to communicate is recognized as a determinant and should be seen as a concern, in their perspective, for nurses. It is often necessary to start communicating through a non-verbal register, an embracing look, and then issuing the first words, showing the will to give continuity, now and always to an embracement context.

They verify that nurses competence in areas such as communication and clinical interaction is fundamental, in order to protect and strengthen them, to identify and construct strategies. Proença and collaborators ${ }^{(24)}$ think that information, as genuine need of family members, must be guaranteed at the time of the visit, by doctors and nurses, which requires two important aspects, professionals must have a respectable communication relationship and both understand the positive impact that therapeutic relationship produced through family and patient.

Good teams, in good services, considering the unpredictability of the critical disease experience, allow families to feel more supported and more comfortable ${ }^{(25)}$. Facing the critical illness situation the recognition and the resolution of identified factors such as barriers to family involvement in the ICU, are the focus ${ }^{(26)}$.

The family easily begins to know in detail the patient unity and realize how they can be useful, recognizing the nurses with whom they have a rich and healthy dialogue. These nurses acknowledge that the family is an endless source of data, which allow the team to have a better awareness of the patient and his family, but at the same time be an essential support for the sick person.

It's my mother, I'm with her every day, I am the right hand of my mother, I'm glad that you come to ask me things about her. "Thank you, I'm glad you came to ask me." Rather than I am feeling important, is more "after all I am needed, after all they do not know everything and they need me to know more things [...]"[...] we need them and they need us. Information must be shared [...] an approach, if we can get along with the health professional, he will have the information he needs and we also [...]. ( FM15)

[...] maybe I could help, information they had obtained in the meantime. I think the family feels it is helping in the recovery process, part of the team that is recovering the sick, I think it's 
more the psychological part also, already involves a number of areas [...] (FM2)

[...] families can also help the sick a lot, if we have the information, good information, we can convey this good information to the patient, because if it is a nurse, a strange person, saying those things to the sick person is not the same thing. (FM15)

Family and care team live a bond in the care, daily built. According to Ribeiro ${ }^{(27)}$, the hospitalization process, associated with the state of health of each person, is a permanence in a place, during a variable period of time. It can be observed that this register requires personal and professional training to nurses, reflection moments and their own analysis, in order to stay healthy and be effective in their actions ${ }^{(28)}$. Rego ${ }^{(29)}$ says that working with patients and their family requires spaces for professionals to reflect and dialogue, about care situations and outcomes achieved, in order to boost creativity and quality response to patients'"requests" and family.

\section{Ensuring comfort}

Within the family, from the existing and built relationship, comfort emerges allowing to work in everyday life the ability to raise awareness of the situation in each family member. Comfort is experienced, is felt, in so is the act of providing comfort. Regarding health professionals, they realize that comfort comes from built therapeutic relationship. Michelan \& Spiri ${ }^{(30)}$, focused on care humanization, realized that the concept of relationship in the care context is essential. Nurses have their care focused in embracing the sick person and his family in a proficiently presence ${ }^{(22)}$. They know that this kind of intervention, when performed daily, brings comfort to the family. The family realizes that for nurses their comfort is decisive, and it becomes visible in a warm embracement, the tranquility transmitted and continuing monitoring.

[...] when he entered the block was when I broke a bit, I came to tears and I was a bit distressed and the nurse who was there came right to me, comforted me and hugged me. She told me to go and get some air because that was going to take some time and also for me not to cry, and that I could rest assured [...] when I went to back in, the nurse came back to me again and reassured me [...] while I was waiting, every once in a while the nurses came with me into the play [...]. (FM10)

[...] having in mind the situation we have, the recovery that was achieved [...] it was through her state of health that we won confidence in the team [...]. (FM2)

[...] I think that being prepared I was not so anxious, then I knew how I had to act with him, how was [...] what I would say [...] if I do not have information, I do not know how do i have to act [...] my father always had a smile [...] always. When I've got next to him, it was like I was[...] I do not know [...] a cuddle [...] my father had hearing difficulties, so there were some things he did not understand, and I was always with him [...] my father started to confront me, and I [...]. (FM4)

It seems that comfort crosses the life of the sick person, his experience, his family and the nurses in the clinical exercise.
Focusing on the sick person and the family, Kolcaba and collaborators $^{(31)}$ refer that the level of comfort of patients and their families influence their decisions, and according to that family engage more fully in health seeking behaviors that include internal behaviors and external behaviors. For Ribeiro(27), the comfort process involves and reveals a continuous building process, where Individual and collective qualities developed throughout life are determinant. To Proença and collaborators ${ }^{(24)}$, comfort comes from interaction; so a good relationship with the family is essential. To construct a individualize care plan it's necessary that the professionals of the ICU knows the patient and family better, either to the lucid patient or to the one with mechanical and/or neurological limitation.

\section{Limitations of the study}

As a limitation of this study we can identify the fact that the traditional generalization of the outcomes is not possible, since this experience is unique. However, the possibility of portability is assumed, since their use may have, in contexts with similar characteristics, implications for care practice.

\section{Contributions to the area of Nursing, Health or Public Policy}

The access to family narratives and to the experience meaning knowledge is essential and determinant for the construction of effective therapeutic interventions, which provides comfort to family members.

It is important that clinical decision centers, clinical intervention contexts and training entities focus on people's experience in order to evaluate the implemented strategies and structure their actions. It is vital to train future and current nurses to use with success qualitative methodologies that make possible to access people's lived experience.

\section{FINAL CONSIDERATIONS}

Taking into account the lived transition experience, making the investigation questions, carefully carried out, intended to meet the research purpose and can be found in the researcher's concern. Facing the problem under study, the methodological option was consistent with the research questions.

In the access to the sources, the intentional selection of the participants considered the research purpose and the relevance of the cases. The aim was to reach a set of rich and detailed data that let us see the lived experience. In order to reply the research questions, it was important that the data subjected to analysis and interpretation were consistent and enough to enable each phase in an iterative way.

Coding was carried out, always looking for the indicative methodological and theoretical frameworks selected and from a significant number of data allowed to clearly identify three essential themes: Being aware; Building dialogue; Ensuring comfort.

Family members seek interaction among themselves and with the members of the care team, particularly with nurses, to be aware of the situation and to progressively understand the present and the future. The prognosis awareness and the 
expected outcomes of therapeutic interventions has proven to be difficult, but made possible to build up a relationship of trust with the care team and bring some comfort. The possibility of being understood and clarified made the experience easier. For the family, the reliable and healthy dialogue with nurses in daily life was decisive in the lived experience. Family is considered by these professionals as an inexhaustible source of knowledge regarding the sick person and a customer care, deserving their particular attention. They have found that these nurses have a humanized care.

\section{REFERENCES}

1. Meleis Al, Sawyer LM, Im EO, Hilfinger Messias DK, Schumacher K. Experiencing transitions: an emerging middle-range theory. ANS Adv Nurs Sci. 2000;23(1):12-28.

2. Sampaio D, Gameiro J. Terapia familiar. Porto (PT): Afrontamento; 1995. 189 p.

3. Relvas AP. Por detrás do espelho: da teoria à terapia familiar. Coimbra (PT): Quarteto; 2003. 213 p.

4. Mendes A. A informação à família na unidade de cuidados intensivos: desalojar o desassossego que vive em si. Loures (PT): Lusodidacta; 2015. $264 \mathrm{p}$.

5. de Souza F, do Espirito Santo FH. O olhar que olha o outro... um estudo com familiares de pessoas em quimioterapia antineoplásica. Rev Bras Cancerol [Internet]. 2008 [cited 2019 Jan 3];54(1):31-41. Available from: http://www1.inca.gov.br/rbc/n_54/v01/pdf/artigo_5_ pag_31a42.pdf

6. Chick N, Meleis. Transitions: a Nursing concern. In: Chinn PL, editors. Nursing research metodology: issues and implantation. Gaithersburg (MD): Aspen; 1986. 235-57 p.

7. Meleis Al, Trangenstein PA. Facilitating transitions: redefinition of the nursing mission. Nurs Outlook. 1994;42(6):255-9.

8. King IM. Enfermería como profesión: filosofia, princípios y objectivos. México: Lisuma; 1984. 189 p.

9. Fernandes CS, Gomes JA, Martins MM, Gomes BP, Gonçalves LH. A Importância das famílias nos cuidados de enfermagem: atitudes dos enfermeiros em meio hospitalar. Rev Enf Ref [Internet]. 2015 [citado 2019 Jan 03];ser IV( 7 ):21-30. Available from: http://dx.doi. org/10.12707/RIV15007

10. de Beer J, Brysiewicz P. The conceptualization of family care during critical illness in KwaZulu-Natal, South Africa. Health AS Gesondheid [Internet]. 2017 [cited 2019 Jan 3]; 22:20-7. Available from: https://doi.org/10.1016/j.hsag.2016.01.006

11. Brinkmann S, Kvale S. Interviews: learning the craft of qualitative research interviewing. Thousand Oaks (CA): Sage Publications; 2009.385 p.

12. Vam Manen M. Researching lived experience. 2 ed. New York: Althouse Press; 1997. 197 p.

13. Davidsen AS. Phenomenological approaches in psychology and health sciences. Qual Res Psychol. 2013;10(3):318-39.

14. Giorgi A, Sousa D. Métpdp fenomenológico de investigação em psicologia. Lisboa: Fim do Século; 2010. 280 p.

15. Benner P, Kyriakidis PH, Stannard D. Critical Wisdom and interventions in acute and critical care. 2 ed. New York: Springer Publishing Company; $2011.600 \mathrm{p}$.

16. Esquivel DN, da Silva GT, Medeiros MO, Soares NR, Fomes VC, da Luz Costa ST. Produçao de estudos em enfermagem sob o referencial da fenomenologia. Rev Baiana Enferm [Internet]. 2016 [cited 2019 Jan 3]; 30(2):1-10. Available from: http://dx.doi.org/10.18471/rbe. v30i2.15004

17. Ordem dos enfermeiros: ninguém está sozinho [Internet]. Dia Internacional da família - enfermeiros e famílias em parceria na construção da saúde para todos. Lisboa: Ordem dos enfermeiros; 2018 [cited 2019 Jan 3]. Available from: https://www.ordemenfermeiros.pt/arquivo-dep\%C3\%A1 ginas-antigas/dia-internacional-da-fam\%C3\%ADlia-enfermeiros-e-fam\%C3\%ADlias-em-parceria-na-constru\%C3\%A7\%C3\%A3oda-sa\%C3\%BAde-para-todos/

18. International Council of Nurses. CIPE versão 2: Classificação Internacional para a Prática de Enfermagem. Lisboa: Ordem dos Enfermeiros; 2011. $205 \mathrm{p}$.

19. McKiernan M, McCarthy G. Family members' lived experience in the intensive care unit: a phemenological study. Intensive Crit Care Nurs. 2010;26(5):254-61. doi: 10.1016/j.iccn.2010.06.004

20. Armitage P, Colton T, editors. Encyclopedia of biostatistics. Cambridge: John Wiley \& Sons; 1997. Vol 6: Nul-Ran.

21. Cohen MZ, Kahn DL, Steeves RH. Hermeneutic phenomenological research: a practical guide for nurse researchers. Thousand Oaks (CA): Sage Publications; 2000. doi: 10.4135/9781452232768

22. Mendes AP. Impact of critical illness news on the family: hermeneutic phenomenological study. Rev Bras Enferm [Internet]. 2018 [cited 2019 Jan 03]; 71(1):170-7. Available from: http://dx.doi.org/10.1590/0034-7167-2016-0163

23. Hinkle JL, Fitzpatrick E. Needs of American relatives of intensive care patients: perceptions of relatives, physicians and nurses. Intensive Crit Care Nurs. 2011;27(4):218-25. doi: 10.1016/j.iccn.2011.04.003

24. Proença VM, de Matos EV, de Souza Campos SM, Toledo Neto JP, Costa AB, Bravo DS, et al. Humanização aos familiares de pacientes em cuidados intensivos. Rev Uningá [Internet]. 2017 [cited 2019 Jan 3];53(1):39-44. Available from: http://revista.uninga.br/index.php/uninga/ 
article/view/1415/1030

25. Mendes AP. Sensibilidade dos profissionais face à necessidade de informação: experiência vivida pela família na unidade de cuidados intensivos. Texto Contexto - Enferm [Internet]. 2016 [cited 2019 Jan 03];25(1):e4470014. Available from: http://dx.doi. org/10.1590/0104-07072016004470014.

26. Hetland B, McAndrew N, Perazzo J, Hickman R. A qualitative study of factors that influence active family involvement with patient care in the ICU: Survey of critical care nurses. Intensive Crit Care Nurs. 2018;44:67-75. doi:10.1016/j.iccn.2017.08.008

27. Ribeiro PC. A natureza do processo de conforto do doente idoso crónico em contexto hospitalar: construção de uma teoria explicativa - projecto integrado de vivência e cuidado co-criado [Thesis on the Internet]. Lisboa: Universidade Católica Portuguesa, Instituto de Ciências da Saúde; 2012 [cited 2019 Jan 3]. 421 p. Available from: https://repositorio.ucp.pt/bitstream/10400.14/12685/1/Tese\%20 Doutoramento\%20-\%20Patr\%C3\%ADcia\%20Pont\%C3\%ADfice\%20Sousa.pdf

28. Pereira-Mendes A. O exercício reflexivo na aprendizagem clínica: subsídio para a construção do pensamento em enfermagem. Rev Elect Educare [Internet]. 2016 [cited 2019 Jan 3];20(1):1-23. Available from: http://dx.doi.org/10.15359/ree.20-1.9

29. Da Silva AC. Reformas no sector da saúde: a equidade em cuidados intensivos [Internet]. Lisboa: Universidade Católica; 2010 [cited 2019 Jan 3]. 16 p. Available from: https://www.uceditora.ucp.pt/resources/Documentos/UCEditora/Indices/Reformas\%20no\%20sector\%20saude\%20ll.pdf

30. Michelan Vanessa Cecilia de Azevedo, Spiri Wilza Carla. Perception of nursing workers humanization under intensive therapy. Rev Bras Enferm [Internet]. 2018 [cited 2019 Jan 03];71(2): 372-8. Available from: http://dx.doi.org/10.1590/0034-7167-2016-0485

31. Kolcaba K, Tilton C, Drouin C. Comfort Theory: a unifying framework to enhance the practice environment. J Nurs Adm. 2006;36(11):538-44. 